\title{
Analysis of seven mineral elements in cultivated fruiting bodies of Cordyceps militaris
}

\author{
Li Fenglin ${ }^{1,2, *}$, Li Li ${ }^{1}$, Jiang Xiaokun ${ }^{1,2}$, Liang Yan ${ }^{1,2}$, and Liu Hengwei ${ }^{1}$ \\ ${ }^{1}$ School of Food Technology, Jilin Agricultural Science and Technology University, 132101 Jilin, China \\ ${ }^{2}$ Brewing Technology Innovation Center of Jilin Province, 132101 Jilin, China
}

\begin{abstract}
The objective of this study was to investigate the content of main mineral elements in cultivated fruiting bodies of Cordyceps militaris. Microwave digestion was used to pretreat Cordyceps militaris samples, and the content of seven mineral elements in Cordyceps militaris was determined by inductively coupled plasma mass spectrometry (ICP-MS). The results showed that the content of arsenic (As), lead $(\mathrm{Pb})$, cadmium $(\mathrm{Cd})$, copper $(\mathrm{Cu})$, silver $(\mathrm{Ag})$, zinc $(\mathrm{Zn})$, and manganese $(\mathrm{Mn})$ in cultivated fruiting bodies of Cordyceps militaris, respectively, is $0.0047 \mathrm{mg} / \mathrm{kg}, 0.22 \mathrm{mg} / \mathrm{kg}, 0.0041 \mathrm{mg} / \mathrm{kg}, 9.1 \mathrm{mg} / \mathrm{kg}, 0.024 \mathrm{mg} / \mathrm{kg}$, $5.2 \mathrm{mg} / \mathrm{kg}$, and $1.6 \mathrm{mg} / \mathrm{kg}$. The content of heavy metals such as $\mathrm{Pb}, \mathrm{Cd}$ and As is within the limits of Chinese national food safety standard. The method used in this study has the advantages of high sensitivity, fast analysis speed, and good reproducibility. It can be used for the determination of mineral elements in cultivated fruiting bodies of Cordyceps militaris.
\end{abstract}

\section{Introduction}

Cordyceps militaris (L.) Link, an entomopathogenic fungus parasitic to Lepidoptera larvae, belonging to the same species as Cordyceps sinensis, and is one of the most important Chinese herbal medicine. It grows in mountainous areas with an altitude of 150 to $500 \mathrm{~m}$, can parasitize on the pupae of various insects, and is widely distributed around the world [1]. In China, the naturally occurring Cordyceps militaris is mainly distributed in Jilin, Liaoning, Hebei, Shanxi, Guangxi, Guangdong, Yunnan, Sichuan, Guizhou, Hubei and Hunan regions. Due to its high production costs, naturally occurring Cordyceps militaris is not easily available. But recently, Jilin Province has realized large-scale artificial cultivation of Cordyceps militaris and achieved good economic benefits. It is commonly used to treat lungs and kidneys, nourish the essence, stop bleeding and phlegm, tuberculosis, weakness and anemi in traditional Chinese medicine [2]. In March 2009, the Ministry of Health of China determined Cordyceps militaris as a new resource food, which can be produced and used as food or food raw materials. Fruit bodies and mycelia of Cordyceps militaris contain various chemical components, such as polysaccharides, cordycepic acid, cordycepin, cordyceps protein, adenosine, and trace elements [3]. Recent research has confirmed that Cordyceps militaris will absorb various mineral elements, especially heavy metal elements, from the culture medium, water and atmospheric environment during its growth process, and its safety will be affected. Heavy metals cannot be degraded by microorganisms, and can be enriched and transformed in the organism, and finally enter the human body through the food chain. Heavy metals in the human body will cause serious harm to the body when it exceeds a certain limit. Therefore, it is necessary to strengthen the detection of the mineral element content of Cordyceps militaris to ensure that its limit conforms to China's national standards.

The microwave digestion method is currently an ideal sample digestion method, which has the characteristics of high heating efficiency, low reagent consumption, no pollution and low loss [4]. Inductively coupled plasma mass spectrometry (ICP-MS) is a mass spectrometry mineral element analysis method with plasma as the ion source, which is mainly used for simultaneous determination of multiple mineral elements. It has the characteristics of many analysis types, high sensitivity, low detection limit, wide linear range, and little interference [5]. In recent years, ICP-MS has been widely used in soil, food, medicine, and plant research. In this study, microwave digestion method was used to pre-treat the samples, and the content of seven mineral elements in cultivated fruiting bodies of Cordyceps militaris was determined by ICP-MS. The research will provide a theoretical reference for the safe use of Cordyceps militaris resources.

\section{Materials and methods}

\subsection{Materials and chemicals}

Cultivated fruiting bodies of Cordyceps militaris was obtained from HuifengTechnology Co., Ltd. (Jilin, China). Standard solutions of arsenic, lead, cadmium,

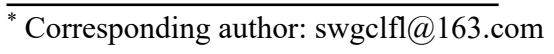


copper, silver, zinc, and manganese were purchased from Yihua Tongbiao Technology Co., Ltd. (Beijing, China). Nitric acid and $30 \%$ hydrogen peroxide were purchased from Baosheng Material Distribution Office (Jilin, China). Deionized water was prepared by a pure water system of Puxi Analysis Instrument Co., Ltd. (Beijing, China). All other reagents are of superior grade.

\subsection{Main instruments}

MASTER 40 high-throughput sealed microwave digestion instrument with a pressure, temperature and time control system was purchased from Xinyi Microwave Chemical Technology Co., Ltd (Shanghai, China). This instrument has a microwave frequency of $2450 \mathrm{MHz}$ and a maximum microwave output power of $2200 \mathrm{~W}$, which can meet the digestion work of 40 digestion tanks. 1000 NexION inductively coupled plasma mass spectrometer (ICP-MS) was purchased from PerkinElmer Co. (Massachusetts, USA), which consists of an inductively coupled plasma ion source, a quadrupole ion deflection extraction system, a quadrupole collision reaction cell, a quadrupole mass filter, and an ion detection system.

\subsection{Sample digestion}

The dried Cordyceps militaris was ground to fine powder and the sample $(0.50 \mathrm{~g})$ was placed in a separate digestion tank, and then $2 \mathrm{~mL}$ of $30 \%$ hydrogen peroxide solution and $5 \mathrm{~mL}$ of unboiled $\mathrm{HNO} 3$ were added to each digestion tank. The digestion tank was sealed, and then placed in the microwave digestion instrument. Sample digestion was carried out according to the procedure specified in Table 1.

Table 1. Reference conditions for microwave digestion.

\begin{tabular}{|c|c|c|c|c|}
\hline Step & $\begin{array}{c}\text { Power } \\
\text { change } \\
(\%)\end{array}$ & $\begin{array}{c}\text { Set } \\
\text { temperatur } \\
\mathrm{e} \\
\left({ }^{\circ} \mathrm{C}\right)\end{array}$ & $\begin{array}{c}\text { Heatin } \\
\text { g time } \\
(\mathrm{min})\end{array}$ & $\begin{array}{c}\text { Constant } \\
\text { temperatu } \\
\text { re time } \\
(\mathrm{min})\end{array}$ \\
\hline 1 & $0-80$ & 120 & 8 & 5 \\
\hline 2 & $0-80$ & 160 & 5 & 10 \\
\hline 3 & $0-80$ & 180 & 5 & 10 \\
\hline
\end{tabular}

After the digestion of the sample was completed, it was cooled to room temperature, and then the digestion tank is taken out, and the excess inorganic acid was removed by heating on the hot plate until the solution was concentrated to about $1.0 \mathrm{~mL}$ to $2.0 \mathrm{~mL}$. The solution was cooled to room temperature and transferred to a $25 \mathrm{~mL}$ volumetric flask. At the same time, the digestion tank was washed with ultrapure water several times, and then the cleaning solution was combined with the digested solution and diluted to $25 \mathrm{~mL}$ with ultrapure water as the test solution.

\subsection{Configuration of mixed standard curve}

The standard reserve solution of each element of Arsenic (As), lead ( $\mathrm{Pb})$, cadmium (Cd), copper( $\mathrm{Cu}$ ), silver(Ag), zinc( $\mathrm{Zn})$, manganese $(\mathrm{Mn})$ was accurately absorbed into the same $100 \mathrm{~mL}$ volumetric flask, and then the mixture standard intermediate solution of concentration of 10 $\mathrm{g} / \mathrm{mL}$ was prepared with $2 \%$ nitric acid solution. The mixture intermediate solution of $1.0 \mathrm{~mL}$ was then absorbed into the $100 \mathrm{~mL}$ volumetric flask and diluted with $2 \%$ nitric acid to prepare $100 \mathrm{ng} / \mathrm{mL}$ mixture standard use solution. The mixture standard use solution of 1.0, 2.0, 4.0, 8.0 and $16.0 \mathrm{~mL}$ was accurately absorbed into a $100 \mathrm{~mL}$ volumetric bottle, and the volume was fixed and mixed with $2 \%$ nitric acid solution. The concentration of the mixed standard series curves after constant volume were 1.0, 2.0, 4.0, 8.0, and $16.0 \mu \mathrm{g} / \mathrm{L}$, respectively. After it was successfully prepared, the mixed standard series solution was placed and stored in a clean polyethylene bottle.

\subsection{Sample determination}

ICP-MS was used to measure samples. The instrument was equipped with the SMARTintro ${ }^{\text {TM }}$ sampling system and the full matrix sampling system (AMS). Samples with high solid content can be injected directly while ensuring the signal Long-term stability. The unique ability of the universal cell can use one gas to realize the collision mode and reaction mode at the same time, effectively remove interference, the switching time is very short, and the detection efficiency is effective. Further details of instrumental settings are given in Table 2.

Table 2. 1000 NexION ICP-MS operating conditions and acquisition parameters.

\begin{tabular}{|c|c||c|c|}
\hline Parameter & $\begin{array}{c}\text { reference } \\
\text { value }\end{array}$ & Parameter & $\begin{array}{c}\text { reference } \\
\text { value }\end{array}$ \\
\hline RF power & $1400 \mathrm{~W}$ & atomizer & Barbinton \\
\hline $\begin{array}{c}\text { carrier gas } \\
\text { flow rate }\end{array}$ & $1.09 \mathrm{~L} / \mathrm{min}$ & $\begin{array}{c}\text { sampling } \\
\text { cone type }\end{array}$ & Nickel cone \\
\hline $\begin{array}{c}\text { compensat } \\
\text { ion gas } \\
\text { flow rate }\end{array}$ & $0 \mathrm{~L} / \mathrm{min}$ & $\begin{array}{c}\text { signal } \\
\text { acquisition }\end{array}$ & Pulse/analog \\
\hline $\begin{array}{c}\text { sampling } \\
\text { depth }\end{array}$ & $6.5 \mathrm{~min}$ & $\begin{array}{c}\text { sample } \\
\text { lifting rate }\end{array}$ & $0.5 \mathrm{rps}$ \\
\hline $\begin{array}{c}\text { S/C } \\
\text { temperatu } \\
\text { re }\end{array}$ & $2{ }^{\circ} \mathrm{C}$ & $\begin{array}{c}\text { sample } \\
\text { vertebral } \\
\text { foramen }\end{array}$ & $1 \mathrm{~mm}$ \\
\hline $\begin{array}{c}\text { creep } \\
\text { collapse } \\
\text { speed }\end{array}$ & $24 \mathrm{rps}$ & $\begin{array}{c}\text { interception } \\
\text { cone } \\
\text { diameter }\end{array}$ & $0.4 \mathrm{~mm}$ \\
\hline
\end{tabular}

The ICP-MS was used to measure the standard curve solution with concentrations of $1,2,4,8,16 \mathrm{~g} / \mathrm{L}$, respectively, and sample blank solution and the solution of the sample to be measured. The calculation formula of mineral element content is as follow.

$$
\rho=\frac{\left(\rho_{1}-\rho_{0}\right) \times V}{m \times 1000}
$$

Where $\rho$ is content of mineral elements in the sample $(\mathrm{mg} / \mathrm{kg}), \rho_{0}$ is mineral element content in reagent blank solution $(\mu \mathrm{g} / \mathrm{L})$, and $\rho_{1}$ is mineral element content in determination sample. Meanwhile, $\mathrm{m}$ is sample mass $(\mathrm{g})$, and $\mathrm{V}$ is total volume of sample digestion solution $(\mathrm{mL})$. 


\section{Results}

\subsection{Analysis of mineral element content in cultivated fruiting bodies of Cordyceps militaris}

The content of mineral elements in cultivated fruiting bodies of Cordyceps militaris is shown in Table 3 . The arsenic (As) content is $0.0047 \mathrm{mg} / \mathrm{kg}$, lead $(\mathrm{Pb})$ content is $0.22 \mathrm{mg} / \mathrm{kg}$, cadmium $(\mathrm{Cd})$ content is $0.0041 \mathrm{mg} / \mathrm{kg}$, copper $(\mathrm{Cu})$ content is $9.1 \mathrm{mg} / \mathrm{kg}$, silver $(\mathrm{Ag})$ content is $0.024 \mathrm{mg} / \mathrm{kg}$, zinc $(\mathrm{Zn})$ content is $5.2 \mathrm{mg} / \mathrm{kg}$, and manganese $(\mathrm{Mn})$ content is $1.6 \mathrm{mg} / \mathrm{kg}$. As can be seen from Table 4, compared with the Chinese national food safety standard "Contaminant Limit in Food" (GB 27622017), the contents of lead, cadmium, and arsenic is all within the maximum limit of contaminants in food and meet the safety standards.

Table 3. Mineral element content in cultivated fruiting bodies of Cordyceps militaris.

\begin{tabular}{|c|c|c|c|c|}
\hline $\begin{array}{l}\text { Mineral } \\
\text { element }\end{array}$ & $\begin{array}{c}\text { As } \\
(\mu \mathrm{g} / \mathrm{L})\end{array}$ & $\begin{array}{c}\mathrm{Pb} \\
(\mu \mathrm{g} / \mathrm{L})\end{array}$ & $\begin{array}{c}\mathrm{Cd} \\
(\mu \mathrm{g} / \mathrm{L})\end{array}$ & $\begin{array}{c}\mathrm{Cu} \\
(\mu \mathrm{g} / \mathrm{L})\end{array}$ \\
\hline \multirow[t]{3}{*}{$\begin{array}{l}\text { signal } \\
\text { value }\end{array}$} & 6759.5 & 312787.1 & 3160.8 & 114903.6 \\
\hline & 7031 & 341080.5 & 3211.6 & 119095.9 \\
\hline & 6558.2 & 304226.3 & 3340.1 & 119692.4 \\
\hline \multirow{3}{*}{$\begin{array}{c}\text { measure } \\
\text { d value } \\
(\mu \mathrm{g} / \mathrm{L})\end{array}$} & 0.277 & 13.092 & 0.231 & 5.287 \\
\hline & 0.299 & 14.315 & 0.241 & 5.493 \\
\hline & 0.261 & 12.723 & 0.266 & 5.522 \\
\hline \multirow{3}{*}{$\begin{array}{c}\text { calculate } \\
\text { d value } \\
(\mathrm{mg} / \mathrm{kg})\end{array}$} & 0.0046 & 0.22 & 0.0038 & 8.8 \\
\hline & 0.0050 & 0.24 & 0.0040 & 9.2 \\
\hline & 0.0044 & 0.21 & 0.0044 & 9.2 \\
\hline $\begin{array}{l}\text { content } \\
(\mathrm{mg} / \mathrm{kg})\end{array}$ & 0.0047 & 0.22 & 0.0041 & 9.1 \\
\hline $\begin{array}{l}\text { Mineral } \\
\text { element }\end{array}$ & $\begin{array}{c}\mathrm{Ag} \\
(\mu \mathrm{g} / \mathrm{L})\end{array}$ & $\begin{array}{c}\mathrm{Zn} \\
(\mu \mathrm{g} / \mathrm{L})\end{array}$ & $\begin{array}{c}\mathrm{Mn} \\
(\mu \mathrm{g} / \mathrm{L})\end{array}$ & - \\
\hline \multirow[t]{3}{*}{$\begin{array}{l}\text { signal } \\
\text { value }\end{array}$} & 21993.5 & 292187.7 & 1759257.9 & - \\
\hline & 24006.9 & 304291.2 & 1897245.5 & - \\
\hline & 23581.9 & 282482.9 & 2010428 & - \\
\hline \multirow{3}{*}{$\begin{array}{c}\text { measure } \\
\text { d value } \\
(\mu \mathrm{g} / \mathrm{L})\end{array}$} & 1.352 & 3.144 & 8.986 & - \\
\hline & 1.450 & 3.263 & 9.630 & - \\
\hline & 1.429 & 3.049 & 10.157 & - \\
\hline
\end{tabular}

\begin{tabular}{|c|c|c|c|c|}
\hline $\begin{array}{c}\text { calculate } \\
\mathrm{d} \text { value } \\
(\mathrm{mg} / \mathrm{kg})\end{array}$ & 0.023 & 5.2 & 1.5 & - \\
\cline { 2 - 5 } & 0.024 & 5.4 & 1.6 & - \\
\cline { 2 - 5 } & 0.024 & 5.1 & 1.7 & - \\
\hline $\begin{array}{c}\text { content } \\
(\mathrm{mg} / \mathrm{kg})\end{array}$ & 0.024 & 5.2 & 1.6 & - \\
\hline
\end{tabular}

Table 4. Limit indicators of contaminants in food.

\begin{tabular}{|c|c|c|}
\hline $\begin{array}{c}\text { Conta } \\
\text { minant }\end{array}$ & $\begin{array}{c}\text { Limit standard for } \\
\text { Contaminant } \\
(\mathrm{mg} / \mathrm{kg})\end{array}$ & $\begin{array}{c}\text { Content of Contaminant in } \\
\text { cultivated fruiting bodies of } \\
\text { Cordyceps militaris } \\
(\mathrm{mg} / \mathrm{kg})\end{array}$ \\
\hline $\mathrm{Pb}$ & $\leq 1.0$ & 0.22 \\
\hline $\mathrm{Cd}$ & $\leq 0.2$ & 0.0041 \\
\hline $\mathrm{As}$ & $\leq 0.5$ & 0.0047 \\
\hline
\end{tabular}

\subsection{Stability test}

The concentration of $4 \mathrm{~g} / \mathrm{L}$ of arsenic, lead, cadmium, copper, silver, zinc and manganese in the control solution was selected, and then was placed at room temperature for $0,2,4,6,8,10,24 \mathrm{~h}$, then the measured value was injected and recorded. The RSD of each mineral element was calculated to be $1.62 \%$ (arsenic), $1.23 \%$ (lead), $1.57 \%$ (cadmium), $1.42 \%$ (copper), $1.36 \%$ (silver), $1.13 \%$ (zinc), and $1.29 \%$ (manganese), respectively. The above results indicate that the test solution is stable within $24 \mathrm{~h}$.

\section{Discussion}

The detection methods of mineral elements mainly include atomic absorption method, atomic fluorescence method, inductively coupled plasma mass spectrometry (ICP-MS) and so on. Atomic absorption method, because different elements need to be changed to different lamps, only one element can be measured at a time, limiting its application [6]. Atomic fluorescence method has limited element range for analysis, and some elements have low sensitivity and narrow linear range. Atomic fluorescence conversion efficiency is low, and the fluorescence intensity is weak, which brings certain difficulties to signal reception and detection. In addition, scattered light has a great influence on atomic fluorescence analysis, which also limits its application [7].

Inductively coupled plasma mass spectrometer (ICP$\mathrm{MS}$ ) is a new element and isotope analysis technique, which combines the high temperature ionization characteristics of ICP ion source with the sensitive and fast scanning advantages of four-pole mass spectrometer [8]. In recent years, ICP-MS has been widely used in the field of mineral element analysis of food, medicine and Chinese herbal medicine [9-11]. 
In this study, microwave combined digestioninductively coupled plasma mass spectrometry was used to simultaneously determine the content of seven mineral elements in cultivated fruiting bodies of Cordyceps militaris. The research results can provide technical reference for the safety evaluation and further development of Cordyceps militaris.

\section{Conclusions}

The analysis of seven mineral elements in the fruiting bodies of Cordyceps militaris is as follows : the arsenic (As) content is $0.0047 \mathrm{mg} / \mathrm{kg}$, lead $(\mathrm{Pb})$ content is 0.22 $\mathrm{mg} / \mathrm{kg}$, cadmium $(\mathrm{Cd})$ content is $0.0041 \mathrm{mg} / \mathrm{kg}$, copper $(\mathrm{Cu})$ content is $9.1 \mathrm{mg} / \mathrm{kg}$, silver $(\mathrm{Ag})$ content is 0.024 $\mathrm{mg} / \mathrm{kg}$, zinc ( $\mathrm{Zn}$ ) content is $5.2 \mathrm{mg} / \mathrm{kg}$, and manganese $(\mathrm{Mn})$ content is $1.6 \mathrm{mg} / \mathrm{kg}$. The content of heavy metals such as $\mathrm{Pb}, \mathrm{Cd}$ and $\mathrm{As}$ are within the limits of Chinese national food safety standard. For these reasons, inductively coupled plasma mass spectrometer is considered very useful for the determination of mineral elements in large fungi, and it is very competitive with other analytical methods used in the same field.

\section{Acknowledgements}

This work was supported by the Science and Technology Project of Jilin Provincial Department of Education (No. JJKH20180732KJ) and College Students Technology Innovation and Entrepreneurship Program of JiLin Agricultural Science and Technology University (No. 2018 040). The authors thank Professor Lu of Jilin City Center for Disease Control for giving the technology support.

\section{References}

1. R. Yu, Y. Yin, W. Yang. Carbohyd. Polym. 75, 1 (2009).

2. J.Y. Cha, H.Y.Ahn, Y.S. Cho, J.Y. Je, Food Chem. Toxicol. 60, 145 (2013).

3. Y. Jin, X. Meng, Z.D Qiu,Y.P. Su, P.Yu, P. Qu, Saudi J. Biol. Sci. 25, 5 (2018).

4. D.J. Owen, S.J. Evans, A. Guirguis, K. Kellett, J.L. Stair. J. Pharm. Pharmacol. 71, 1 (2019)

5. S. Kilic, M. Soylak. J. Food Sci. Tech. Mys. 57, 3 (2020).

6. F. Fiamegkos, P. Cordeiro, D. Robouch, V. Vélez, G. Devesa, J.J. Raber, R.R. Sloth, T. Rasmussen. Food Chem. 75, 1 (2016).

7. Z. Long, J.J. Xin, X.D. Hou. Spectrosc Lett. 37, 3 (2004).

8. M.Y. He, H. Lu, C.G. Luo, T.X. Ren. Microchem. J. 127, 4 (2016).

9. V. Acierno, L. Jonge, S. Ruth. Food Res. Inter. 133, 28 (2020).

10. L. Fu, S.Y. Shi. Food Chem. 299, 7 (2019).
11. E.V. Oral, Ö. Tokul-Ölmez, İ.Yener, M. Firat, Z. Tunay, P. Terzioğlu, F. Aydin, M. Öztürk, A. Erta. Anal. Lett. 52, 2 (2019). 